\title{
1H-2-Benzothiopyran-4(3H)-one in Aldol and Mannich Reactions
}

\author{
ØYVIND HAMMER JOHANSEN, TOR OTTERSEN and KJELL UNDHEIM
}

Department of Chemistry, University of Oslo, Oslo 3, Norway

The title compound (1) has been converted to (Z)-3-alkylidene derivatives by aldol condensation with butanal or benzaldehyde. The 3 . methylene derivative, expected from the reaction with formaldehyde, dimerized spontane. ously to a spiro compound (6), which was also obtained from 1 through a Mannich reaction. The stereochemistry of 6 has been investigated by $X$-ray techniques.

Hydride abstraction from $1 H$-2-benzothiopyran$4(3 H)$-one 1 (Scheme 1) or its 1-methyl derivative has yielded 4-hydroxy-2-benzothiopyrylium salts.1,2 The betaines of the latter are rapidly dimerized to syn- and anti-5,6,12,13-tetrahydro-5,13:6,12-bisepithiodibenzo[ $a, f]$ cyclodecene7,14-diones (4). This report describes studies of 3-alkylidene derivatives 2 which are isomeric with the thiopyrylium betaines 3 .

The lithium enolate of $1 H$-2-benzothiopyran$4(3 H)$-one ${ }^{3}$ was generated at $-78^{\circ} \mathrm{C}$ by means of lithium diisopropylamide (LDA), and the enolate reacted with butanal. The initial aldol
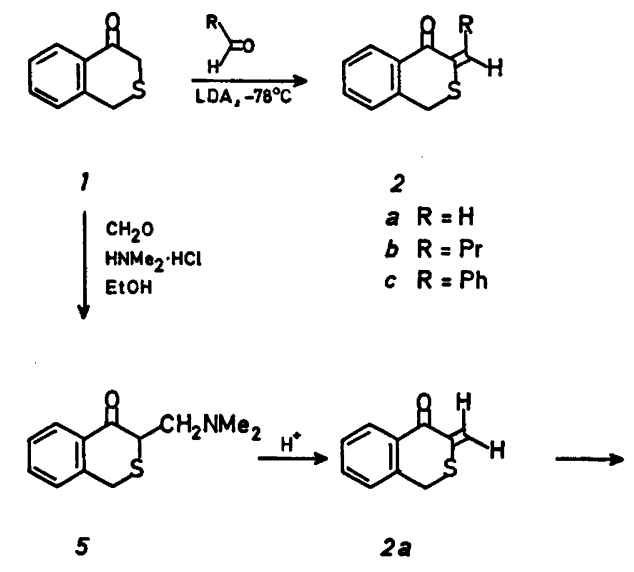

Scheme 1.

0302-4369/79/090669-06\$02.50

(C) 1979 Acta Chemica Scandinavica was dehydrated in the strongly basic medium. Acetaldehyde with the enolate gave a heterogeneous reaction product, presumably because of metal-hydrogen exchange between acetaldehyde and the enolate of 1 followed by reactions of the new enolate.4a The aldol condensation proceeded well for benzaldehyde. In IR, the carbonyl band for $2 b$ was at $1685 \mathrm{~cm}^{-1}$ and for $2 c$ at $1665 \mathrm{~cm}^{-1}$. $M$ was the base peak in the mass spectra. The benzylic protons on $\mathrm{C}-1$ appear as a singlet at $c a$. $\delta$ 3.8. Among the aromatic protons, $\mathrm{H}-5$ resonates at the lowest field due to the anisotropy effect of the carbonyl group. ${ }^{1}$ Spectroscopy and chromatography are consistent with formation of one stereoisomer. The latter is expected to have the $\beta$-vinyl substituent trans to the carbonyl group. ${ }^{4 b}$ trans configuration is also supported by comparisons of ${ }^{1} \mathrm{H}$ NMR spectra. In 2-methylenecyclohexanone the cis proton with respect to the carbonyl group resonates at $\delta 5.72$ and the trans proton at $\delta 5.04 .^{5}$ In (E)-2-butyl-6-butyl-<smiles></smiles>
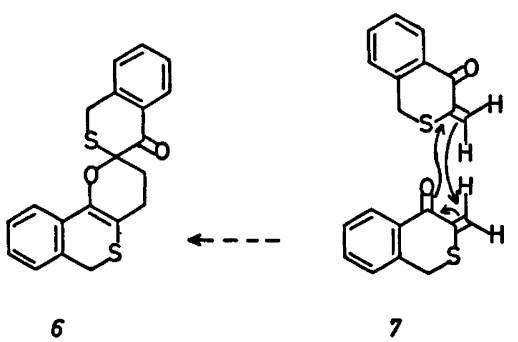


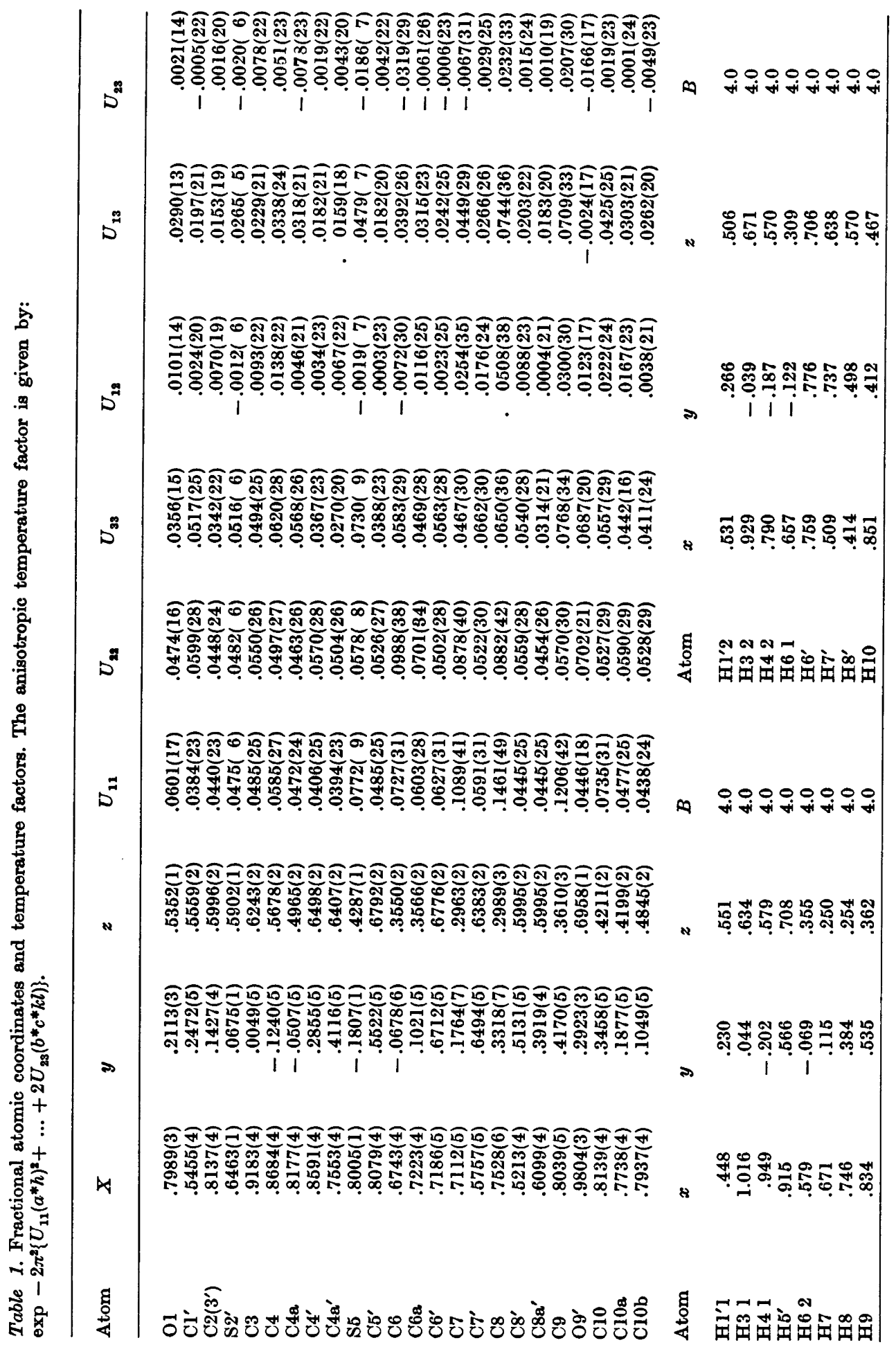

Acta Chem. Scand. B 33 (1979) No. 9 
Table 2. Deviations from least-squares planes $\left(\AA \times 10^{3}\right)$. The deviations for those atoms used to define a plane is marked with *.

\begin{tabular}{|c|c|c|c|c|}
\hline Atom & Plane A & Plane B & Atom & Plane C \\
\hline O1 & -358 & $-84^{*}$ & OI & -1054 \\
\hline $\mathrm{C} 2\left(3^{\prime}\right)$ & & -287 & $\mathrm{Cl}^{\prime}$ & -29 \\
\hline C3 & & 525 & $\mathrm{C} 2\left(3^{\prime}\right)$ & -131 \\
\hline C4 & 1021 & $118^{*}$ & $\mathrm{S2}^{\prime}$ & 777 \\
\hline C4a & 627 & $-11 *$ & C3 & 321 \\
\hline $\mathrm{C4}^{\prime}$ & & 116 & $\mathrm{C}^{\prime}{ }^{\prime}$ & 119 \\
\hline S5 & 1115 & $-35^{*}$ & $\mathrm{C} 4 \mathbf{a}^{\prime}$ & $7 *$ \\
\hline C6 & -38 & -885 & $\mathrm{C5}^{\prime}$ & $1 *$ \\
\hline C6a & $4^{*}$ & -214 & C6' & $-8 *$ \\
\hline C7 & $-6^{*}$ & & C7' & $7 *$ \\
\hline C8 & $2 *$ & & $\mathrm{C8}^{\prime}$ & $1 *$ \\
\hline $\mathrm{C9}$ & $3^{*}$ & & $\mathrm{C} 8 \mathbf{a}^{\prime}$ & $-8^{*}$ \\
\hline $\mathrm{ClO}$ & $-4^{*}$ & 712 & $\mathrm{O} 9^{\prime}$ & 393 \\
\hline $\mathrm{ClOa}$ & $0^{*}$ & $133^{*}$ & & \\
\hline $\mathrm{ClOb}$ & 99 & $-33^{*}$ & & \\
\hline
\end{tabular}

idenecyclohexanone the cis proton is at even lower field, viz. at $\delta 6.5,{ }^{6}$ which compares well with the chemical shifts for the vinyl protons in $2 b$ and $2 c$ which overlap with the signals from the aromatic protons at ca. $\delta 7$. Hence $2 b$ and $2 c$ are assigned the $(Z)$-configuration which structurally corresponds to the $(E)$-configuration in cyclohexane analoques.

The methylene derivative $2 a$ was not available for comparison of the ${ }^{1} \mathrm{H}$ NMR data. Attempts to prepare $2 a$ gave other products. Thus when gaseous formaldehyde, which was generated by pyrolysis of paraformaldehyde, was passed into a solution of the lithium enolate of 1 a dimer of $2 a$ was obtained. The same compound was more conveniently made by subjecting 1 to the Mannich reaction with formaldehyde and dimethylamine. The molecular ion in the mass spectrum was at $m / e \mathbf{3 5 2}$ $\left(\mathrm{C}_{20} \mathrm{H}_{16} \mathrm{O}_{2} \mathrm{~S}_{2}\right)$ with base peak at $m / e \quad 176$ $\left(\mathrm{C}_{10} \mathrm{H}_{8} \mathrm{OS}\right)$; the mass spectrum is consistent with a dimer of $2 a$. The carbonyl absorption at $1695 \mathrm{~cm}^{-1}$ was at the same position as in 1 ; a new band at $1630 \mathrm{~cm}^{-1}$ indicated a carboncarbon double bond. In ${ }^{1} \mathrm{H}$ NMR, one of the eight aromatic protons appeared at $\delta 8.1$, the others in the region $\delta 7.0-7.5$. Two isolated methylene groups were shown by an AB quartet at $\delta 3.48$ and $4.34, J 17 \mathrm{~Hz}$, and by a slightly split two-proton signal at $\delta$ 3.83. Four unresolved signals in the region $\delta 1.9-2.8$ suggested an ethylene bridge in a complex environment. An $X$-ray structure determination showed that the compound had the spiro-structure 6 . The compound was difficult to purify because of decomposition reactions which presumably orginate in the reactive monothioketal function in which the oxygen atom is also part of an enol ether.

The same product 6 was also obtained when the Mannich reaction was run in acetic acid. In the absence of dimethylamine no reaction between 1 and formaldehyde took place. Hence the formation of 6 is rationalized by formation of the Mannich product which subsequently undergoes elimination to $2 a$. The latter is dimerized by a Diels-Alder reaction (7) in the regioselective manner expected from the polarization of $2 a$. The reaction is analogous to dimerizations of the $\alpha, \beta$-unsaturated aldehydes acrolein and methacrolein to 2-formyl-2,3-di-

Table 3. Selected torsional angles $\left({ }^{\circ}\right)$. The angles are positive in a right-hand screw.

$$
\begin{aligned}
& \mathrm{C} 2\left(3^{\prime}\right)-\mathrm{C} 1^{\prime}-\mathrm{S} 2^{\prime}-\mathrm{C} 8 \mathrm{a}^{\prime} \\
& \mathrm{C} 8 \mathrm{a}^{\prime}-\mathrm{C} 4 \mathrm{a}^{\prime}-\mathrm{C} 2\left(3^{\prime}\right) \\
& \mathrm{C} 4 \mathrm{a}^{\prime}-\mathrm{C} 4^{\prime}-\mathrm{C} 2\left(3^{\prime}\right)-\mathrm{S} 2^{\prime} \\
& \mathrm{C} 1^{\prime}-\mathrm{S} 2^{\prime}-\mathrm{C} 2\left(3^{\prime}\right)-\mathrm{O} 1 \\
& \mathrm{~S} 2^{\prime}-\mathrm{C} 2\left(3^{\prime}\right)-\mathrm{O} 1-\mathrm{C} 10 \mathrm{~b} \\
& \mathrm{O} 1-\mathrm{C} 2\left(3^{\prime}\right)-\mathrm{C} 3-\mathrm{C} 4 \\
& \mathrm{C} 2\left(3^{\prime}\right)-\mathrm{O} 1-\mathrm{C} 10 \mathrm{~b}-\mathrm{C} 10 \mathrm{a} \\
& \mathrm{C} 4 \mathrm{a}-\mathrm{C} 10 \mathrm{~b}-\mathrm{C} 10 \mathrm{a}-\mathrm{C} 6 \mathrm{a} \\
& \mathrm{C} 7-\mathrm{C} 6 \mathrm{a}-\mathrm{C} 6-\mathrm{S} 5 \\
& \mathrm{C} 6-\mathrm{S} 5-\mathrm{C} 4 \mathrm{a}-\mathrm{C} 10 \mathrm{~b} \\
& \mathrm{C} 4 \mathrm{a}-\mathrm{C} 4-\mathrm{C} 3-\mathrm{C} 2\left(3^{\prime}\right) \\
& \hline
\end{aligned}
$$

$$
\begin{aligned}
& \mathrm{S} 2^{\prime}-\mathrm{C} 1-\mathrm{C} 8 \mathrm{a}^{\prime}-\mathrm{C} 4 \mathrm{a}^{\prime} \\
& \mathrm{C} 5^{\prime}-\mathrm{C} 8 \mathrm{a}^{\prime}-\mathrm{C} 4^{\prime}-\mathrm{O} 9^{\prime} \\
& \mathrm{C} 4 \mathrm{a}^{\prime}-\mathrm{C} 4^{\prime}-\mathrm{C} 2\left(3^{\prime}\right)-\mathrm{O} 1 \\
& \mathrm{C} 1^{\prime}-\mathrm{S} 2^{\prime}-\mathrm{C} 2\left(3^{\prime}\right)-\mathrm{C} 3 \\
& \mathrm{C} 3-\mathrm{C} 2\left(3^{\prime}\right)-\mathrm{O} 1-\mathrm{Cl} 10 \mathrm{~b} \\
& \mathrm{~S} 2^{\prime}-\mathrm{C} 2\left(3^{\prime}\right)-\mathrm{C} 3-\mathrm{C} 4 \\
& \mathrm{C} 2\left(3^{\prime}\right)-\mathrm{O} 1-\mathrm{C} 10 \mathrm{~b}-\mathrm{C} 4 \mathrm{a} \\
& \mathrm{O} 1-\mathrm{C} 10 \mathrm{~b}-\mathrm{C} 10 \mathrm{a}-\mathrm{C} 10 \\
& \mathrm{C} 6 \mathrm{a}-\mathrm{C} 6-\mathrm{S} 5-\mathrm{C} 4 \mathrm{a} \\
& \mathrm{C} 10 \mathrm{~b}-\mathrm{C} 4 \mathrm{a}-\mathrm{C} 4-\mathrm{C} 3
\end{aligned}
$$



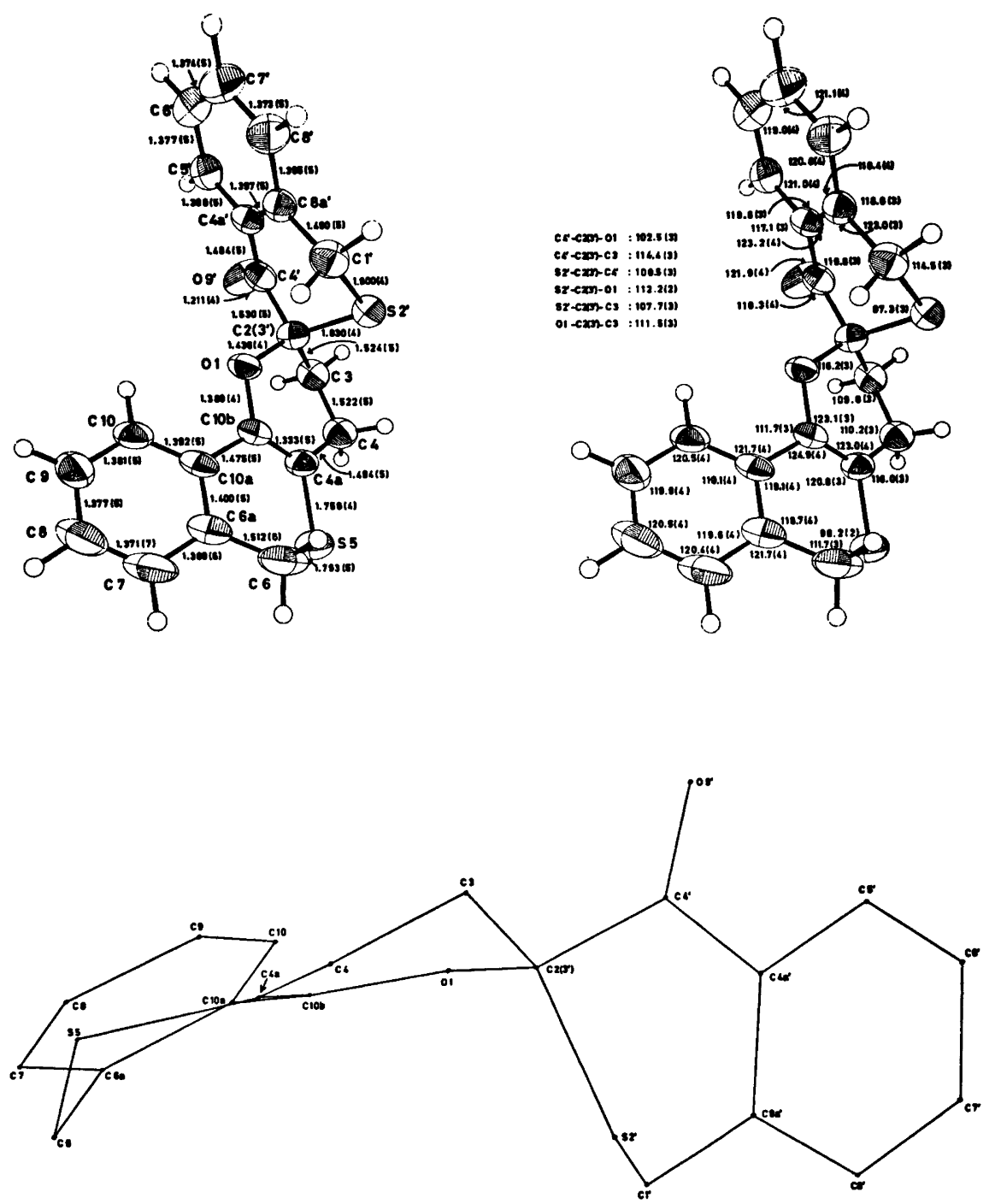

Fig. 1. Bond lengths $(\AA)$ and bond angles $\left({ }^{\circ}\right)$.

hydro-4H -pyrans. ${ }^{7,8}$ 2-Methylenecyclohexanone has also been dimerized on heating and the product on the basis of its chemical properties was assigned the spiro structure which corresponds to $6 .^{\circ}$

The compounds 2 are isomeric with the thiopyrylium betaines 3 . Our attempts, however, to isomerize 2 to 3 using perchloric acid, boron trifluoride, or lithium tetrafluoroborate were unsuccessful.

The molecular geometry of structure 6 together with bond lengths, bond angles and numbering of the atoms is given in Fig. 1. The bond lengths are normal. Some bond angles show deviations probably caused by strain in the ring system. The configuration around the double bond $\mathrm{C} 4 \mathrm{a}-\mathrm{Cl} 0 \mathrm{~b}$ deviates significantly from planarity, and the angle between the plane of the benzene ring $\mathrm{C6a}-$ $\mathrm{ClOa}$ and the plane defined by the atoms around the double bond is $25^{\circ}$. The thiopyranone ring has the sulfur out of the plane through the other 
atoms of the ring. The other heterocyclic rings have twisted chair conformations (Tables 2 and 3 ).

The shortest intermolecular distances are compatible with normal van der Waals' contacts.

\section{EXPERIMENTAL}

(Z)-3-Butylidene-1H-2-benzothiopyran-4(3H)one 2b. Freshly distilled (NaH) diisopropylamine $(3.6 \mathrm{ml}, 25 \mathrm{mmol})$ was added by means of a syringe to freshly distilled $\left(\mathrm{LiAlH}_{4}\right) \mathrm{THF}$ $(25 \mathrm{ml})$, the solution cooled to $0^{\circ} \mathrm{C}$ and butyllithium (1.45 M, $17.3 \mathrm{ml}, 25 \mathrm{mmol}$ ) added by means of a syringe under purified nitrogen gas. The mixture was stirred for $10 \mathrm{~min}$ at $0^{\circ} \mathrm{C}$ before a solution of $1 \mathrm{H}$-2-benzothiopyran-4(3H)-one $(4.10 \mathrm{~g}, 25 \mathrm{mmol})$ in anhydrous THF $(50 \mathrm{ml})$ was added dropwise with stirring at $0^{\circ} \mathrm{C}$. The mixture was stirred for $10 \mathrm{~min}$ before the tem. perature was lowered to $-78^{\circ} \mathrm{C}$. A solution of freshly distilled $\left(\mathrm{CaH}_{2}\right)$ butanal $(2.2 \mathrm{ml}, 25$ $\mathrm{mmol}$ ) in anhydrous THF $(25 \mathrm{ml})$ was added dropwise with stirring at this temperature. When the addition was completed, the mixture was left overnight at room temperature before it was poured into ice-cold water $(50 \mathrm{ml})$ and the mixture stirred for $30 \mathrm{~min}$. The mixture was extracted with ether, the dried ( $\left.\mathrm{MgSO}_{4}\right)$ ether extracts evaporated, and the residual oily material subjected to thick-layer chromatography on silica gel $60 \mathrm{PF}_{254}(1.5 \mathrm{~mm})$ using dichloromethane to develop the plates. The major band with $R_{F}$ 0.6-0.8 was scraped off, the organic material extracted into dichloromethane, the solution evaporated and the residue subjected to preparative GLC on Apiezon L (10\%; $2.4 \mathrm{~m}$; ret. time ca. $8 \mathrm{~min})$ at $250^{\circ} \mathrm{C}$. The product was an oily material; yield $41 \%$. MS: $M$ m/e 218.0771; calc. for $\mathrm{C}_{13} \mathrm{H}_{14} \mathrm{OS:}$ : 218.0766. ${ }^{1} \mathrm{H}$ NMR $\left(\mathrm{CDCl}_{3}\right): \delta 0.95$ $\left(3 \mathrm{H}-4^{\prime}, \mathrm{t}\right), 1.3-1.9\left(2 \mathrm{H}-3^{\prime}, \mathrm{m}\right), 2.3\left(2 \mathrm{H}-2^{\prime}, \mathrm{q}\right)$, 3.86 (2 H-1, s), 7.0-7.4 (H-6,7,8, $\left.\mathrm{l}^{\prime}, \mathrm{m}\right), 8.1$ $(\mathrm{H}-5)$. IR $\left(\mathrm{CHCl}_{3}\right): 1685$ ( $\alpha, \beta$-unsat. $\left.\mathrm{CO}\right), 1655$ $\mathrm{cm}^{-1}(\mathrm{C}=\mathrm{C}) . \mathrm{MS}$ [70 eV m/e (\% rel.int.)]: 218 $(100, M), 217(9), 189$ (15), 185 (7), 177 (7), 176 (46), $161(24), 128(12), 119(13), 118$ (64).

(Z)-3-Benzylidene-1H-2-benzothiopyran$4(3 \mathrm{H})$-one $2 \mathrm{c}$. The reaction was carried out as above using freshly distilled $\left(\mathrm{CaH}_{2}\right)$ benzaldehyde. The crude product was purified by chromatography on a column of neutral alumina. The title compound was eluted with chloroform; yield $48 \%$ m.p. $94-95^{\circ} \mathrm{C}$ (light petroleum b.p. $80-100^{\circ} \mathrm{C}$. Anal. $\mathrm{C}_{18} \mathrm{H}_{12} \mathrm{OS}: \mathrm{C}, \mathrm{H}$. ${ }^{1} \mathrm{H}$ NMR $\left(\mathrm{CDCl}_{3}\right): \delta 3.88(2 \mathrm{H}-1, \mathrm{~s}), 7.1-8.2$ $(10 \mathrm{H})$. IR $\left(\mathrm{CCl}_{4}\right)$ : $1665 \mathrm{~cm}^{-1}$ ( $\alpha, \beta$-unsat. $\left.\mathrm{CO}\right)$. $\mathrm{UV}\left[\mathrm{CHCl}_{3}, \lambda_{\max }(\log \varepsilon)\right]: 370(3.59), 280(4.18)$ nm. MS [70 eV m/e (\% rel. int.)]: $252(100, M)$, 251 (88), 223 (6), 119 (6), 118 (57), 90 (36), 89 (14).

Acta Chem. Scand. B 33 (1979) No. 9
3,4-Dihydro-2H,6H-2-benzothiopyrano [4,3-b]pyran-2-spiro-3'- $[1 \mathrm{H}-2]$ benzothiopyran $-4^{\prime}\left(3^{\prime} \mathrm{H}\right)$ one 6. Method $A$. $1 H$-2-Benzothiopyran-4(3H)one $(3.0 \mathrm{~g}, 18 \mathrm{mmol})$, dimethylamine hydrochloride (1.5 g, $20 \mathrm{mmol}$ ) and paraformaldehyde $(2.0 \mathrm{~g}, 21 \mathrm{mmol})$ were dissolved in abs. ethanol $(50 \mathrm{ml})$ and the solution acidified to $\mathrm{pH} c a .1 .5$ by ethanolic $\mathrm{HCl}$. The resultant mixture was refluxed for $8 \mathrm{~h}$ and then left at room tempera. ture overnight. The precipitate was chromatographed on a column of neutral alumina and the title compound eluted with dichloromethane. The product can be recrystallized from carbon tetrachloride; yield $44 \%$, m.p. $174-175^{\circ} \mathrm{C}$. The yield of material isolated could be increased by evaporation of the original reaction mixture and subjecting the total residue to chromatographic separation as above. MS: $M m / e$ 352.0600; calc. for $\mathrm{C}_{20} \mathrm{H}_{18} \mathrm{O}_{2} \mathrm{~S}_{2}$ : 352.0591. ${ }^{1} \mathrm{H}$ NMR $\left(\mathrm{CHCl}_{3}\right): \delta 2.0-2.8(4 \mathrm{H}$, $\left.\mathrm{CH}_{2}-\mathrm{CH}_{2}, \mathrm{~m}\right), 3.48$ and $4.34(2 \mathrm{H}, \mathrm{AB}, J 17 \mathrm{~Hz})$, 3.83 ( $2 \mathrm{H}$, broad s), $7.0-7.5$ ( $7 \mathrm{H}, \mathrm{m}$ ), 8.1 $(\mathrm{H}-8, \mathrm{~m})$. IR $\left(\mathrm{CHCl}_{3}\right): 1695$ (CO), $1630 \mathrm{~cm}^{-1}$ $(\mathrm{C}=\mathrm{C})$. UV [ $\left.\mathrm{CHCl}_{3}, \lambda_{\max }(\log \varepsilon)\right]: 295(3.71), 330$ (3.67) $\mathrm{nm}$. MS [70 $\mathrm{eV}$ m/e (\% rel. int.)]: 352 (3, M), $202(4), 177$ (11), $176(100), 147$ (6), 119 (10), $118(97), 91(5), 90(56)$.

Method B. Paraformaldehyde, dried over $\mathrm{P}_{2} \mathrm{O}_{5}$, was thermally depolymerized and the gaseous formaldehyde passed into a solution of one equivalent of the lithium enolate of $1 H$-2-benzothiopyran-4(3H)-one in THF, which was prepared as above, at $-20^{\circ} \mathrm{C}$ under an atmosphere of purified nitrogen. When the addition was completed, the mixture was kept at $0^{\circ} \mathrm{C}$ for $2 \mathrm{~h}$ and then stirred at room temperature overnight. Water was added and the stirring continued for $30 \mathrm{~min}$. The organic layer was collected, evaporated and the residue dissolved in chloroform and chromatographed on a silica gel column. Elution with chloroform gave the title compound in $23 \%$ yield.

\section{Crystallographicsection}

The compound was recrystallized from carbon tetrachloride. Oscillation and Weissenberg diagrams showed monoclinic symmetry and the systematic absences characteristic of the space group $P 2_{1} / c$.

The crystallographic work was carried out on a Syntex $\mathrm{P} \overline{1}$ diffractometer with graphite monochromatized MoK$\alpha$ radiation. Cell dimensions were determined from diffractometer measurements of fifteen reflections with $2 \theta$. values between 20 and $30^{\circ}$. The temperature was maintained within $1^{\circ}$ at $19^{\circ} \mathrm{C}$.

Three-dimensional intensity data were collected by the $\omega-2 \theta$ scanning mode with scan speeds variable from 3 to $12^{\circ} \min ^{-1}(2 \theta) \mathrm{de}$ pending on the peak intensity of the reflection. Background counting time was $0.35 \times$ scan time on each side of the scan area which was 
from $2 \theta\left(\alpha_{1}\right)-0.75^{\circ}$ to $2 \theta\left(\alpha_{2}\right)+0.9^{\circ}$. The intensities of three standard reflections wihch were remeasured after every sixty reflections, were stable throughout the run. The standard deviations were based on counting statistics with a $2 \%$ addition of the net intensity. Of the 2570 reflections measured $\left(2 \theta_{\max }=45^{\circ}\right) 1552$ had intensities larger than twice their standard deviations. These were regarded as observed, whereas the remaining were excluded from further calculations. The intensities were corrected for Lorentz and polarization effects. The computer program used as well as programs subsequently employed, is part of a local library. ${ }^{10}$ Literature values for the atomic form factors for sulfur, oxygen and carbon, ${ }^{11}$ and for hydrogen ${ }^{12}$ were used. In the full matrix leastsquares program the quantity minimized was $\sum w \Delta F^{2}$ where $w$ is the inverse of the variance of the observed structure factor.

The phase problem was solved by the program assembly MULTAN 77.13 The structure model was refined to an $R$ of 0.11 . Introduction of anisotropic temperature factors for all nonhydrogen atoms and least-squares refinements lowered $R$ to 0.07 . The hydrogen atoms were placed in calculated positions and included in the structure factor calculations with isotropic temperature factors of $4.0 \AA^{2}$. The leastsquares refinements of all parameters involving nonhydrogen atoms converged to an $R$ of 0.043 and an $R_{\mathrm{w}}$ of 0.037 . A difference Fourier synthesis showed only small spurious peaks. Final atomic parameters are given in Table 1 . The experimental data may be obtained from the authors upon request.

\section{CRYSTAL DATA}

\section{3,4-Dihydro-2H,6H-2-benzothiopyrano[4,3-b]-} pyran-2-spiro-3'-[1H-2]benzothiopyran-4'(3'H). one, $\mathrm{C}_{20} \mathrm{H}_{18} \mathrm{O}_{2} \mathrm{~S}_{2}, M=352.48$; space group $P 2_{1} / c$, $a=10.773(2) \AA, b=8.394(2) \AA, c=21.475(2) \AA$, $\beta=118.21^{\circ}(1), \quad V=1711.2(5) \AA^{3}, Z=4, D_{\text {calc }}=$ $1.367 \mathrm{~g} \mathrm{~cm}^{-3}, F(000)=432$.

\section{REFERENCES}

1. Undheim, K. and Baklien, S. J. Chem. Soc. Perkin Trans. 1 (1975) 1366.

2. Baklien, S., Groth, P. and Undheim, K. Acta Chem. Scand. B 30 (1976) 24.

3. Price, C. C., Hori, M., Parasaran, T. and Polk, M. J. Am. Chem. Soc. 85 (1963) 2278.

4. Nielsen, A. T. and Houlihan, W. J. Org. React. 16 (1968); $a$, p. 63; $b$, p. 12.

5. Matter, U. E., Pascual, C., Pretsch, E., Pross, A., Simon, W. and Sternhell, S. Tetrahedron 25 (1969) 2023.

6. Posner, G. H., Sterling, J. J., Whitten, C. E., Lentz, C. M. and Brunelle, D. J. J. Am. Chem. Soc. 97 (1975) 107.
7. Alder, K. and Rüden, E. Ber. Dtsch. Chem. Ges. 74 (1941) 920.

8. Lutz, R. P. and Roberts, J. D. J. Am. Chem. Soc. 83 (1961) 2198.

9. Mannich, C. Ber. Dtsch. Chem. Ges. 74 (1941) 557.

10. Groth, P. Acta Chem. Scand. 27 (1973) 1837.

11. Doyle, P. A. and Turner, P. S. Acta Crystallogr. A 24 (1968) 390.

12. Stewart, R. F., Davidson, E. R. and Simpson, W. T. J. Chem. Phys. 42 (1965) 3175.

13. Germain, G., Main, P. and Woolfson, M. M. Acta Crystallogr. A 27 (1971) 368.

Received May 2, 1979. 